\title{
The effect of energy intake on age at puberty in gilts
}

\author{
L. A. den Hartog and G. J. Noordewier
}

Department of Animal Nutrition, Agricultural University, Haagsteeg 4, 6708 PM Wageningen, Netherlands

Received 4 April 1984; accepted 1 November 1984

Key-words: energy intake, puberty, fertility, oestrus, gilt, nutrition, feeding, fatness

\section{Summary}

The effect of level of energy intake on age and weight at spontaneous first oestrus has been measured in 680 Dutch Landrace gilts. Gilts without an oestrus before the age of 38 weeks were induced.

Four different energy levels (about 3.0 M, 2.5 M, 2.1 M and 1.8 M; M= metabolizable energy required for maintenance) were applied from 12 to 38 weeks of age. Protein intake was similar and was adjusted for weight. At the two higher levels of energy intake more gilts $(9.3 \%$ and $7.7 \%$ ) needed to be culled, compared to the two lower levels of energy intake $(2.4 \%$ and $4.7 \%)$. The number of gilts with a spontaneous oestrus was not significantly affected by the level of energy intake ( 69 , 75,71 and $68 \%$, respectively). Average daily gain and backfat thickness at $99 \mathrm{~kg}$ and at 187 days of age increased at a higher energy intake $(P<0.01)$. At a high level of energy intake gilts reached oestrus at a younger age and with a heavier weight $(P<0.01)$ compared to lower levels. The age and weight at first oestrus were 234 , 237, 237 and 244 days and 139, 131, 118 and $109 \mathrm{~kg}$, respectively.

At the two higher levels of energy intake age at spontaneous first oestrus was negatively related to backfat thickness $(P<0.05)$, while this relation was not found at the lower levels of energy intake.

Average daily gain and backfat thickness were similar for gilts with a spontaneous oestrus or no oestrus at all. Gilts with an induced oestrus had somewhat reduced values for average daily gain and backfat thickness.

Reaching puberty will be determined more by age of the gilt than by weight. However, at a high level of energy intake $(\geqslant 2.5 \mathrm{M})$ fatness of the body acts as a threshold for reaching puberty. First oestrus is delayed when energy intake is less than $70 \%$ of ad libitum. A high fat gäin in gilts has no detrimental effects on reaching puberty. 


\section{Introduction}

Reproduction rate in female pigs is important with regard to sow productivity. Considerable variations in reproductive rate between animals are observed (NRLO, 1979; den Hartog, 1980). Heritability of most of the reproductive traits is low (Legault, 1970; Hutchens et al., 1981), therefore the effects of environment are very important.

Nutrition is an important aspect of these environmental factors. The effects of level of nutrition and especially energy intake during the period between weaning and reaching puberty are not very clear, moreover, results from studies reported in the literature are conflicting (Shearer \& Adams, 1973; Rerat \& Duée, 1975; den Hartog, 1980; den Hartog \& van Kempen, 1980). Another problem is that most of the trials were made with rather few animals. Often also the variation between animals and treatments for various traits was considerable. Especially for studies on fertility, there is a need for large-scale experiments (den Hartog \& van Kempen, 1980).

Variation in energy intake will result in a large variation in amount of body fat at puberty and rate of gain of the gilts up to that age (den Hartog \& Verstegen, 1984). The relation between rate of development in gilts and reproductive traits has not been studied adequately. Therefore, an experiment was performed in which the effects of four different levels of energy intake with a similar protein intake on these traits were studied in gilts. The effect of degree of fatness in gilts on the onset of oestrus was studied. These studies were performed since the decrease in fatness of gilts may have been the result of selection against fatness. Moreover, changes in feeding strategy during the last years may have resulted in a change of reproductive performance. This may also have influenced the relationship between fatness and age at puberty. Since the post weaning feeding level is more dependent on management than during the suckling period, it was decided to study the effect of feeding level from 12 weeks of age to first oestrus.

\section{Material and methods}

The experiment was performed in 9 consecutive batches with 680 Dutch Landrace gilts, progeny of A.I. boars for 3-5 generations. The interval between the start of two consecutive batches was three months.

Gilts from the age of 12 weeks were assigned to one of four feeding treatments which was applied up to the end of the first three weeks of the insemination period (26 weeks later). Creep feed (13.43 MJ metabolizable energy (ME), $15.4 \%$ CP, $1.10 \%$ total lysine) was available ad libitum during the suckling period. Sows were supplied with $2.5 \mathrm{~kg}$ of the diet plus $0.25 \mathrm{~kg}$ for each piglet (from day 21 of lactation onwards). After weaning, at 5 weeks, the piglets were fed ad libitum until they were 10 weeks. From 10 until 12 weeks the piglets were adapted to the experimental feeds at a restricted feeding scheme (increase from 0.5 to $1.2 \mathrm{~kg}$ of feed per day). Dams of gilts of batch 1 to 4 had another feeding scheme at rearing (see van der Steen, 1983) than batches 5 to 9 , in which dams were reared at one of the four feed- 


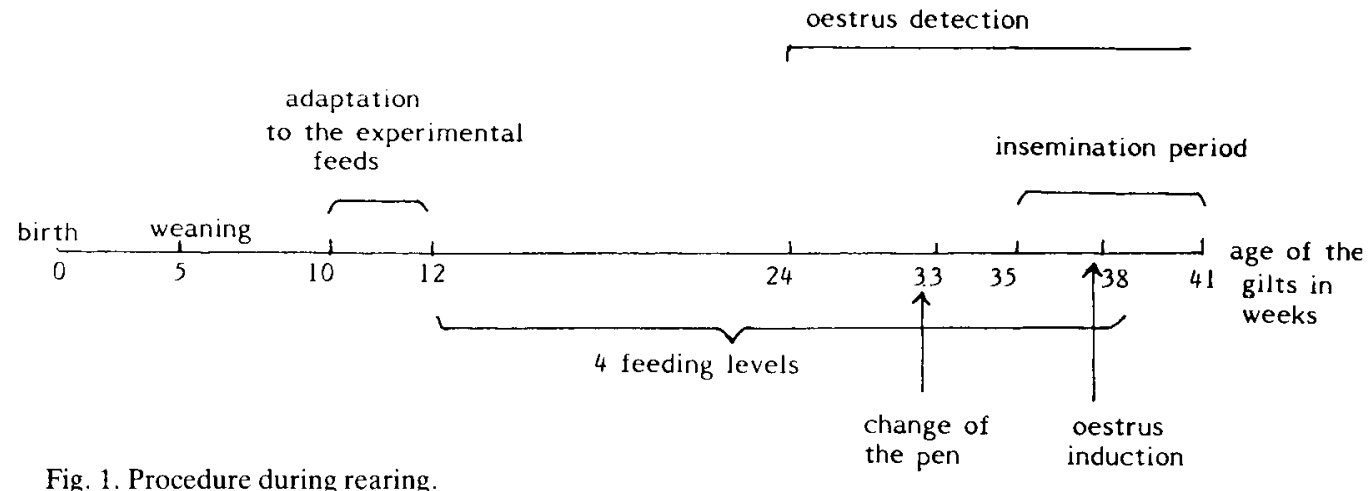

Fig. 1. Procedure during rearing.

ing levels (gilts of batch 5 were progeny of batch 1, etc.). However, feeding level during rearing had no effect on birth weight of the piglets (Hemmer, 1984). During lactation, sows were always fed according to the same scheme.

On reaching the age of 24 weeks the gilts were checked daily for oestrus, both visually and with a teaser boar. A red or pale vulva and showing a standing reflex for the boar were used as signs of oestrus. Gilts were inseminated within a period of 6 weeks after they had reached 35 weeks of age. Gilts which did not show oestrus before the age of 38 weeks were injected intramuscularly with 400 IU of pregnant mare serum and $200 \mathrm{IU}$ of human chorion gonadotrophin (PG600; Intervet, Boxmeer, Netherlands). The procedure during rearing is given in Fig. 1. The points of time mentioned are overall averages of the batches. The range of ages within one batch was three weeks.

\section{Animals}

Female piglets were selected every three months from about 24 primiparous litters at an average age of 10 weeks. Each batch consisted of 80 gilts except batches 5 ( 72 gilts), 4 and 8 (each 64 gilts). Four gilts were selected from each litter as far as possible. Animals of four litters were called a unit together on the basis of similar weight and divided over the four treatments. Each of the four gilts of one litter was assigned to one of the treatments. Four gilts of one treatment within a batch were assigned to a pen in the barn randomly. Gilts remained together in a pen from 10 weeks until the end of pregnancy (290 gilts) or until slaughtering, when reproductive organs were analysed (den Hartog 1984, in preparation).

\section{Housing}

The pens in wich the gilts were housed had a partially slatted floor system. Ambient temperature was maintained at a minimum of $17^{\circ} \mathrm{C}$. Light/dark regime provided light from $08 \mathrm{~h} 00$ to $20 \mathrm{~h} 00$ and darkness from $20 \mathrm{~h} 00$ to $08 \mathrm{~h} 00$. At 33 weeks of age all groups of four gilts were transferred to another pen. This was carried out to stimulate the onset of oestrus (Du Mesnil du Buisson \& Signoret, 1962). 


\section{Feeding}

From 12 until 38 weeks of age each group of four gilts received one of four energy levels at a similar protein level. In order to obtain four equidistant levels of energy intake with a similar protein intake on a weight basis, each diet was made up from a different combination of two experimental feeds (an energy-rich feed A and a protein-rich feed B). Composition of the feeds and the feeding level are given by den Hartog \& Verstegen (1984). Feeding levels were aimed at 3.0 M ( $\mathrm{M}=$ metabolizable energy required for maintenance), $2.5 \mathrm{M}, 2.1 \mathrm{M}$ and $1.8 \mathrm{M}$ (Treatment $1,2,3$ and 4 , respectively).

Differences between energy levels were based on equidistancy in metabolizable energy available for growth. Protein was supplied to provide $120 \%$ of crude protein above the expected maximum protein gain. Protein was given to enable a similar protein gain for gilts on each feeding level. The gilts were fed per pen once a day. Feed was sampled in each batch and the composite sample was analysed for dry matter, protein, fat, crude fibre and ash. To check the quality of the protein in the diet the amino acid composition was determined as described by Bongers (1983). The results of the analyses are presented in Table 1. The contents of vitamins and minerals of feed A and B are given by den Hartog \& Verstegen (1984).

Table 1. Composition of the feeds $\mathrm{A}$ and $\mathrm{B}$ during the experiment (mean \pm standard deviation). Values are mass fractions in fresh matter $(\%)(n=9)$.

\begin{tabular}{lll}
\hline & Feed A & Feed B \\
Dry matter & $85.01 \pm 0.69$ & $88.52 \pm 0.50$ \\
Ash & $4.72 \pm 0.10$ & $15.33 \pm 0.54$ \\
Crude protein & $9.08 \pm 0.13$ & $44.21 \pm 1.53$ \\
Crude fat & $2.98 \pm 0.34$ & $2.45 \pm 0.27$ \\
Crude fibre & $2.31 \pm 0.22$ & $4.08 \pm 0.79$ \\
& & \\
Amino acids & & \\
cystine & 0.22 & 0.63 \\
aspartic acid & 0.68 & 4.72 \\
methionine & 0.22 & 0.93 \\
threonine & 0.36 & 2.07 \\
serine & 0.48 & 2.33 \\
glutamic acid & 1.83 & 5.99 \\
proline & 0.91 & 2.01 \\
glycine & 0.37 & 2.20 \\
alanine & 0.57 & 2.04 \\
valine & 0.47 & 2.37 \\
isoleucine & 0.36 & 2.16 \\
leucine & 0.93 & 3.71 \\
tyrosine & 0.39 & 1.95 \\
phenylalanine & 0.51 & 2.42 \\
lysine & 0.31 & 2.97 \\
histidine & 0.28 & 1.14 \\
arginine & 0.50 & 2.71 \\
tryptophan & 0.07 & 0.49 \\
\hline
\end{tabular}


Feed residues were collected and feed intake adjusted accordingly. An additional experiment to the composition of the feed residues showed that this was similar to the rations fed (Vermeeren, 1981). The level of energy intake of the littermates in the other three pens within a unit were determined from the energy intake at the highest feeding level. Energy intake in metabolizable energy was calculated with the data obtained in the balance trials of den Hartog \& Verstegen (1984). The influence of weight or age on the metabolizability was not taken into account. Feed allowance was calculated on the basis of similar weight as in Treatment 1. Pigs were weighed every two weeks. Water was available ad libitum from nipple drinkers. After the experimental period, which lasted from 12 to 38 weeks, all gilts received 2.5 $\mathrm{kg}$ of feed per day (12.18 MJ ME per $\mathrm{kg}, 15.1 \%$ crude protein $(\mathrm{CP}), 0.70 \%$ total lysine).

\section{Measured and calculated traits}

The following traits were determined:

during rearing: feed intake per pen $\left(\mathrm{kg} \mathrm{d}^{-1}\right)$

energy intake per four gilts per day (MJ $\mathrm{ME} \mathrm{d}^{-1}$ )

weight at two week intervals $(\mathrm{kg})$

rate of gain from 35 to $95 \mathrm{~kg}\left(\mathrm{~g} \mathrm{~d}^{-1}\right)$

backfat thickness (ultrasonically) at a fixed weight of $99 \mathrm{~kg}$ and at an average age of 187 days $(\mathrm{mm})$

protein and fat gain $\left(\mathrm{g} \mathrm{d}^{-1}\right)$ (see den Hartog \& Verstegen, 1984)

at oestrus: age (d)

weight $(\mathrm{kg})$

Statistical analysis

Preliminary results showed that there were no significant differences in productive and reproductive traits between units. Interactions were also not significant. Therefore the data were analysed according to the following model:

$$
Y_{i j k}=\mu+\mathrm{T}_{\mathrm{i}}+\mathrm{B}_{\mathrm{j}}+\mathrm{e}_{\mathrm{ijk}}
$$

in which: $\quad Y_{i j k}=$ dependent variable

$$
\begin{aligned}
& \mu=\text { mean } \\
& \mathrm{T}_{i}=\text { treatment }(i=1 \ldots, 4) \\
& B_{j}=\text { batch }(j=1 \ldots, 9) \\
& \boldsymbol{e}_{i j k}=\text { error }
\end{aligned}
$$

Age at first oestrus for gilts, which did not show first oestrus spontaneously, was estimated, assuming normality, and making use of the calculated median and the fraction of gilts without a spontaneous oestrus per treatment and per batch and a calculated standard deviation of 19 days (adjusted data, see van der Steen, 1983).

When backfat thickness at $99 \mathrm{~kg}$ and at 187 days were used as dependent variable, weight and age at measuring were included in model 1 respectively: 


$$
Y_{i j k}=\mu+\mathrm{T}_{\mathrm{i}}+\mathrm{B}_{\mathrm{j}}+b x_{i j k}+e_{i j k}
$$

in which: $\quad Y_{i j k}=$ backfat thickness at ca. $99 \mathrm{~kg}(\mathrm{~mm})$

and $x_{i j k}=$ weight at measuring $(\mathrm{kg})$ or

$Y_{i j k}=$ backfat thickness at ca. 187 days of age (mm)

and $x_{i j k}=$ age at measuring (days)

$b=$ regression coefficient

In order to calculate regression coefficients between backfat thickness and age at first oestrus within treatments, model 3 was used to analyse data of each treatment.

$$
Y_{j k}=\mu+B_{j}+b_{1} V_{\mathrm{jk}}+b_{2} X_{\mathrm{jk}}+b_{3} Z_{j k}+e_{j k}
$$

in which: $\quad Y_{i k}=$ age at puberty (days)

$\mu=$ mean

$\mathrm{B}_{j}=$ batch $(\mathrm{j}=1 \ldots, 9)$

$V_{j k}=$ backfat thickness at $99 \mathrm{~kg}$ (or at 187 days) (mm)

$X_{j k}=$ weight at backfat thickness measuring $(\mathrm{kg})$

$Z_{j k}=$ age at backfat thickness measuring (days)

$b_{1}, b_{2}, b_{3}=$ multiple regression coefficients

$e_{j k}=$ error

The pooled regression coefficient of age at first oestrus on backfat thickness was also determined with treatment $\left(\mathrm{T}_{\mathrm{i}} i=1,2,3,4\right)$ added to model 3 (model 4).

Protein and fat gain were calculated as described by den Hartog \& Verstegen (1984). Therefore, average daily energy intake and average daily gain of 5 successive periods of 4 weeks and a last period of 6 weeks were calculated. The points in Fig. 3 and 4 are referring to the mean weight in the middle of the periods.

Protein gain, fat gain and fat content of the body in gilts were calculated by assuming that within each pen all gilts had a similar feed intake. The amount of body fat at $95 \mathrm{~kg}$ and at oestrus was calculated. The fat content at the start of the experiment was estimated by the formula of de Wilde (1977): $y=-1.46+0.19 \mathrm{~W}$

in which: $\quad y=$ fat content of the body (in $\mathrm{kg}$ )

$W=$ body weight $($ in $\mathrm{kg}$ )

\section{Results}

\section{Health and culling}

Animals at the experimental farm showed signs of Atrophic Rhinitis in the batches 7,8 and 9 . Therefore in these batches oxytetracycline $400 \mathrm{mg} / \mathrm{kg}$ was added to feed A for periods of 3 weeks intermittent with no addition. However, the addition did not influence the traits since there were no differences between animals of batches 7,8 and 9 and those in batches 1 to 6.41 Gilts out of $680(6.0 \%)$ were culled during the experimental period (see Table 2). The main reason for culling was locomotion disorder (17 gilts). At the two higher feeding levels more animals (16 and 13) had to be culled than at the lower levels ( 4 and 8 ). 
Table 2. Number of gilts with or without a spontaneous or induced oestrus for the four treatment groups.

\begin{tabular}{lccccc}
\hline Number of gilts & \multicolumn{2}{l}{ Treatment } & & $\chi^{2}$ test \\
\cline { 2 - 5 } & 1 & 2 & 3 & 4 & \\
With oestrus & 129 & 139 & 153 & 147 & 1 \\
$\quad$ with spontaneous oestrus & 107 & 116 & 116 & 112 & 2 \\
$\quad$ with induced oestrus & $22^{\mathrm{a}}$ & $23^{\mathrm{ab}}$ & $37^{\mathrm{b}}$ & $35^{\mathrm{ab}}$ & 3 \\
With no oestrus after induction & $19^{\mathrm{a}}$ & $11^{\mathrm{ab}}$ & $5^{\mathrm{b}}$ & $13^{\mathrm{ab}}$ & 4 \\
Not induced and no oestrus & 8 & 5 & 6 & 4 & 5 \\
Culled & $16^{\mathrm{a}}$ & $13^{\mathrm{a}}$ & $4^{\mathrm{b}}$ & $8^{\mathrm{ab}}$ & 6 \\
Total & 172 & 168 & 168 & 172 & 7 \\
\hline
\end{tabular}

1 Data in the same row with a different superscript differ $(P<0.05)$. The effects tested with $\chi^{2}$ test:

- number of gilts with a spontaneous oestrus from total gilts not culled (2)

- number of gilts with an induced oestrus from total induced gilts ( 3 and 4)

- number of culled gilts from total gilts (6).

Table 3. Production traits for gilts reared on one of the four feeding levels (mean \pm standard deviation).

\begin{tabular}{|c|c|c|c|c|c|}
\hline & \multicolumn{4}{|l|}{ Treatment } & \multirow[t]{2}{*}{$\mathrm{CV}^{1}$} \\
\hline & 1 & 2 & 3 & 4 & \\
\hline Weight at start $(\mathrm{kg})$ & $27.1 \pm 4.9$ & $27.3 \pm 4.7$ & $27.1 \pm 5.5$ & $26.9 \pm 5.1$ & \\
\hline Weight after 26 weeks $(\mathrm{kg})$ & $158.1 \pm 17.9$ & $146.6 \pm 15.1$ & $132.9 \pm 15.0$ & $117.3 \pm 14.1$ & \\
\hline Energy intake in 26 weeks (MJ ME) & $6352 \pm 418$ & $5416 \pm 314$ & $4550 \pm 291$ & $3778 \pm 273$ & \\
\hline Age at $95 \mathrm{~kg}$ (days) & 177 & 186 & 200 & 221 & $10.0^{2}$ \\
\hline \multicolumn{6}{|l|}{ Average daily gain from } \\
\hline 35 to $95 \mathrm{~kg}\left(\mathrm{~g} \mathrm{~d}^{-1}\right)$ & 749 & 681 & 595 & 511 & $11.8^{2}$ \\
\hline \multicolumn{6}{|l|}{ Energy intake from 35 to } \\
\hline $95 \mathrm{~kg} /$ growth (MJ ME kg-1) & 40.2 & 37.6 & 37.6 & 37.9 & $9.3^{2}$ \\
\hline \multicolumn{6}{|l|}{ Backfat thickness (mm) at } \\
\hline $99 \mathrm{~kg}$ & 13.6 & 11.8 & 10.7 & 9.7 & $17.1^{2}$ \\
\hline 187 days & 14.7 & 11.8 & 9.5 & 7.7 & $22.7^{2}$ \\
\hline
\end{tabular}

${ }^{1}$ Coefficient of variation calculated as (residual standard deviation $/$ mean $) \times 100$.

2 Probability of treatment and batch $(P<0.01)$.

\section{Effect of level of energy intake on production traits}

Data on rate of gain, 'feed conversion' and backfat thickness are presented in Table 3. Initial weight per treatment was similar for all four treatments.

After the experimental period of 26 weeks the weight of gilts in the four feeding levels differed significantly between each level $(P<0.01$, see Fig. 2$)$. The difference between gilts in the highest and lowest level was about $40 \mathrm{~kg}$. The difference in energy intake during the 26-week experimental period between treatments was nearly equidistant with each lower level about $84 \%$ of the higher level. Rate of gain from 35 to $95 \mathrm{~kg}$ and backfat thickness at $99 \mathrm{~kg}$ and at 187 days of age were significantly affected by level of energy intake $(P<0.01)$. At the higher levels of en- 


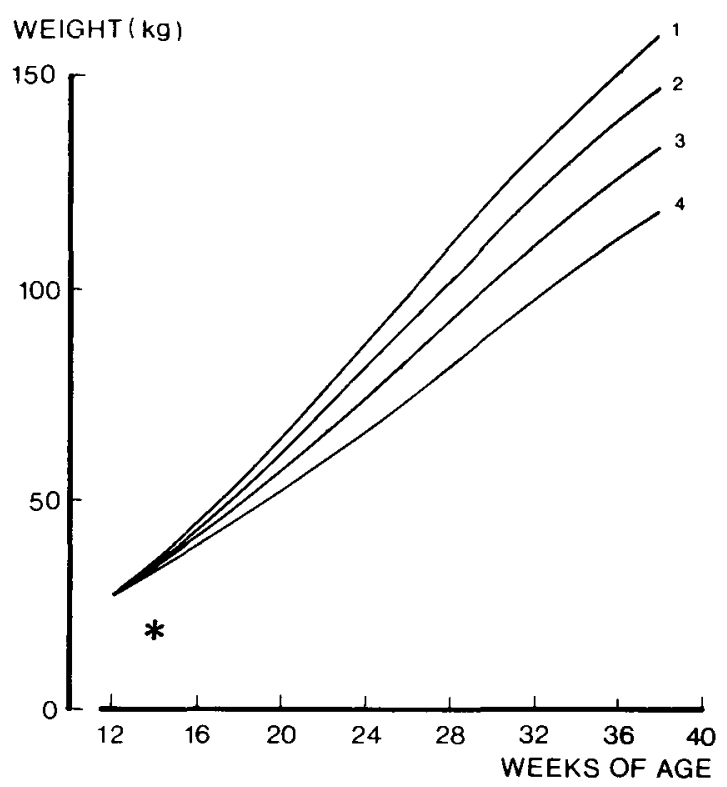

Fig. 2. Weight of the gilts $(\mathrm{kg})$ at the four treatment groups and at different ages (weeks). ${ }^{*}$ From week 14 onwards differences are significant.

ergy intake, rate of gain and backfat thickness were increased. The feed conversion (MJ ME per $\mathrm{kg}$ growth) from 35 to $95 \mathrm{~kg}$ liveweight was also increased at the highest level of energy intake $(P<0.01$; see Table 3$)$. Rate of gain, backfat thickness and feed conversion between the various batches differed significantly (Table 3 ). The data on energy intake are presented in Table 4 . This table shows an increase in energy intake when weight of the animals is higher.

The calculated daily protein and fat gain for gilts at the four energy levels are presented in Fig. 3 and 4, respectively. At a similar weight, gilts with a lower energy intake (Treatments 3 and 4 ) had a reduced protein gain per day, despite the longer time on experiment. In the first half of the experiment, the protein gain per day at a

Table 4. Calculated quantity of energy consumed (MJ metabolizable energy $\mathrm{d}^{-1}$ ) during rearing per pig for the four treatment groups.

\begin{tabular}{|c|c|c|c|c|}
\hline \multirow[t]{2}{*}{ Weight $(\mathrm{kg})$} & \multicolumn{4}{|c|}{ Treatment } \\
\hline & 1 & 2 & 3 & 4 \\
\hline 25 & 16.05 & 13.17 & 11.43 & 10.17 \\
\hline 50 & 26.47 & 22.23 & 19.22 & 17.16 \\
\hline 75 & 34.86 & 29.72 & 25.68 & 23.04 \\
\hline 100 & 41.21 & 35.52 & 31.03 & 28.07 \\
\hline 125 & 45.65 & 39.26 & 35.17 & 31.99 \\
\hline
\end{tabular}




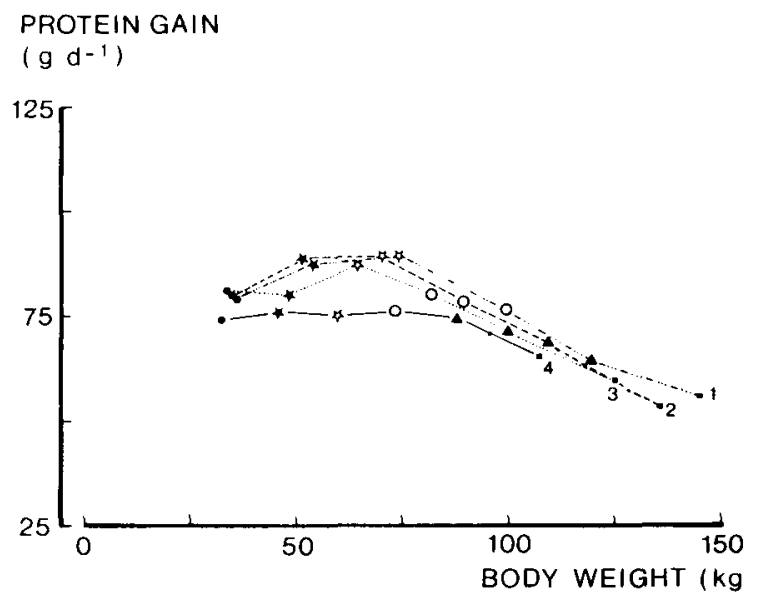

Fig. 3. Protein gain ( $\mathrm{g}$ per day per gilt) for gilts at the four treatment groups and at various body weights.

fixed age (same sign in Fig. 3) was increased when energy intake was increased ( $P$ $<0.01$, while the values were nearly similar in the second half. Fat gain per day was decreased when energy intake was reduced $(P<0.01)$.

Effect of level of energy intake on age at first oestrus

Before the change of pen at 33 weeks of age more gilts in the higher levels of energy intake showed oestrus than in the lower levels $(48,41,38$ and 23 gilts respectively; $P=0.04)$. Two weeks after the change of pen the number of gilts with a spontaneous oestrus in the four levels of energy intake was similar $(85,81,87$ and 72 gilts respectively; $P=0.70$ ).

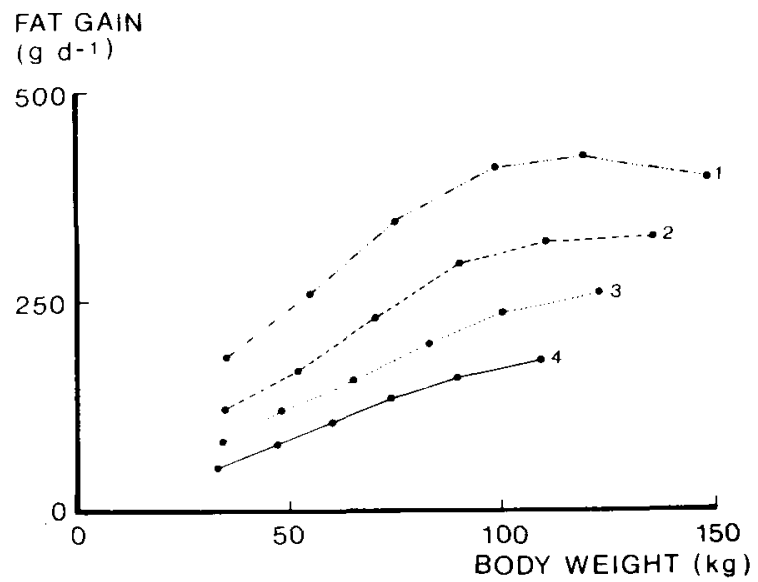

Fig. 4. Fat gain (g per day per gilt) for gilts at the four treatment groups and at various body weights. 
Table 5. Age and weight at first oestrus for sows with a spontaneous and induced oestrus and calculated with adjusted data for all sows.

\begin{tabular}{|c|c|c|c|c|c|c|c|}
\hline & \multicolumn{4}{|c|}{ Treatment } & \multirow[t]{2}{*}{$\mathrm{CV}^{1}$} & \multicolumn{2}{|l|}{ Probability } \\
\hline & 1 & 2 & 3 & 4 & & treatment $\mathrm{b}$ & batch \\
\hline \multicolumn{8}{|l|}{ Sows with a spontaneous oestrus: } \\
\hline age at first oestrus (d) & 234 & 237 & 237 & 244 & 7.6 & 0.00 & 0.00 \\
\hline weight at first oestrus $(\mathrm{kg})$ & 139 & 131 & 118 & 109 & 12.1 & 0.00 & 0.00 \\
\hline \multicolumn{8}{|l|}{ Sows with an induced oestrus: } \\
\hline age at first oestrus (d) & 260 & 262 & 265 & 262. & 5.3 & 0.68 & 0.30 \\
\hline weight at first oestrus $(\mathrm{kg})$ & 152 & 139 & 130 & $1 \mathrm{i} 2$ & 11.5 & 0.00 & 0.10 \\
\hline $\begin{array}{l}\text { Adjusted data for sows } \\
\text { without a spontaneous oestrus }\end{array}$ & & & & & & & \\
\hline age at first oestrus (d) & 246 & 247 & 247 & 254 & 8.5 & 0.00 & 0.00 \\
\hline
\end{tabular}

The number of sows which showed oestrus spontaneously with on average 38 weeks of age was not significantly affected by level of energy intake $\left(\chi_{3}^{2}=2.05, P\right.$ $=0.65$; see Table 2$)$. Gilts with an increased energy intake reached oestrus at a younger age and a higher weight than those in the other treatments $(P<0.01$; see Table 5). The differences in mean age at first oestrus of sows with a spontaneous oestrus for the four treatment groups (Treatment $1-$ Treatment $4=-10$ days, r.s.d. $=18.2$ ) were relatively small compared to the differences in weight (Treatment $1-$ Treatment $4=30 \mathrm{~kg}$, r.s.d. $=15.1$ ). Sows without an oestrus before 38 weeks of age were induced. Treatment differences in age at first oestrus for those gilts were absent.

In Treatment 1 fewer gilts responded to an oestrus induction with PG600 than those in Treatment $3(P<0.05)$ with Treatments 2 and 4 intermediate (Table 2). Twenty-three sows did not show oestrus and were also not induced because they showed pro-oestrus signs (swollen and red vulva) before the end of the insemination period.

Age at first oestrus calculated with adjusted data for sows without a spontaneous oestrus was 254 days for the gilts at the lowest energy intake level, while this age was 246 to 247 days for gilts of the other treatment groups $(P<0.01)$.

Fig. 5 and 6 present the cumulative percentage of gilts with a spontaneous oestrus by age and weight at first oestrus for the four treatments. Gilts with the lowest level of energy intake reached puberty at an older age. Weight at first oestrus differed clearly between the four treatments. Fig. 7 presents the average daily gain from 35 to $95 \mathrm{~kg}$ and the age at first oestrus for gilts with a spontaneous oestrus.

The variation in age at first oestrus between pens was significantly higher than within pens, except for Treatment 3 . The F probabilities of these tests for Treatments $1,2,3$ and 4 were $0.002,0.006,0.317$ and 0.010 , respectively. Fig. 8 gives the mean age at first oestrus and the rate of gain from $35 \mathrm{~kg}$ to $95 \mathrm{~kg}$ of all gilts with a spontaneous oestrus for the different batches. Differences in age and weight at puberty between batches were significant $(P<0.01)$. 
CUMULATIVE PROPORTION

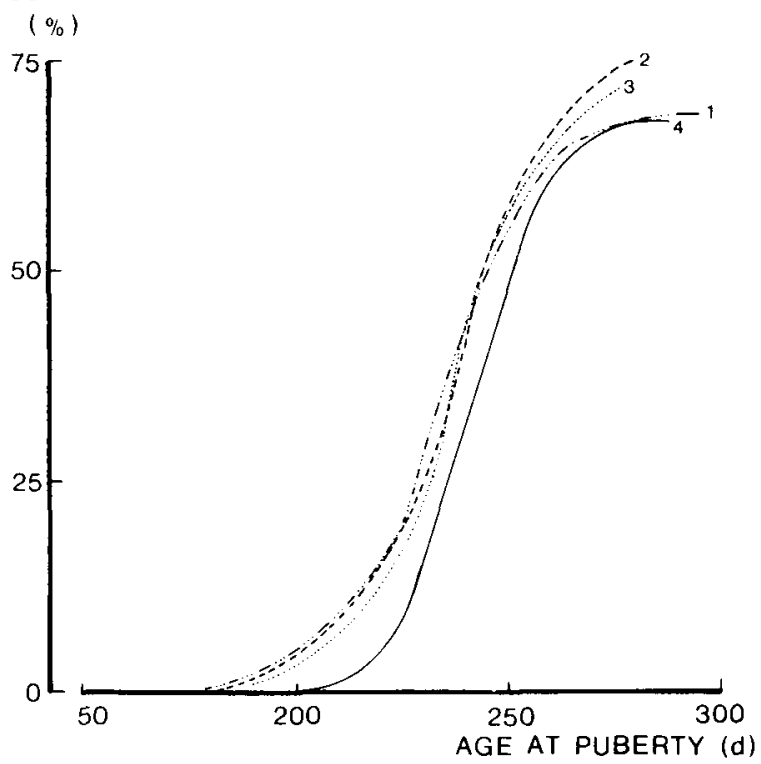

Fig. 5. The cumulative proportion $(\%)$ of gilts with a spontaneous oestrus at various ages for the four treatment groups. (It was calculated until the percentage of gilts with a spontaneous oestrus)

\section{CUMULATIVE PROPORTION}

$(\%)$

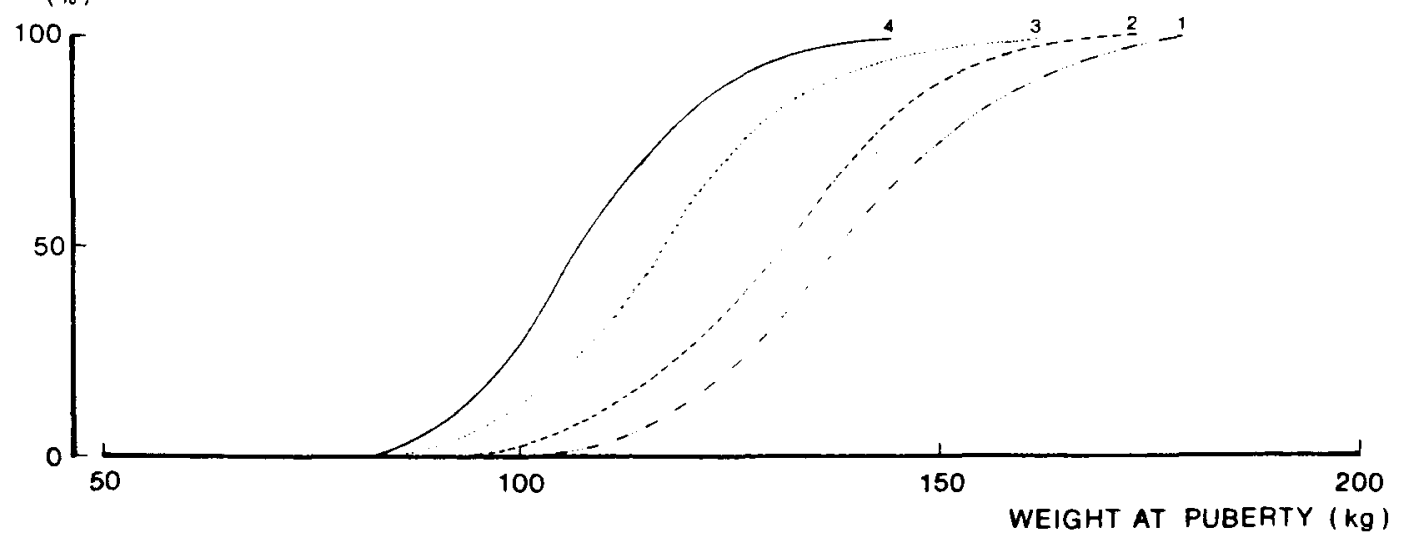

Fig. 6. The cumulative proportion (\%) of gilts with a spontaneous oestrus with various weights at oestrus for the four treatment groups. (It was calculated until 100\%) 


\section{AGE AT PUBERTY}

(d)

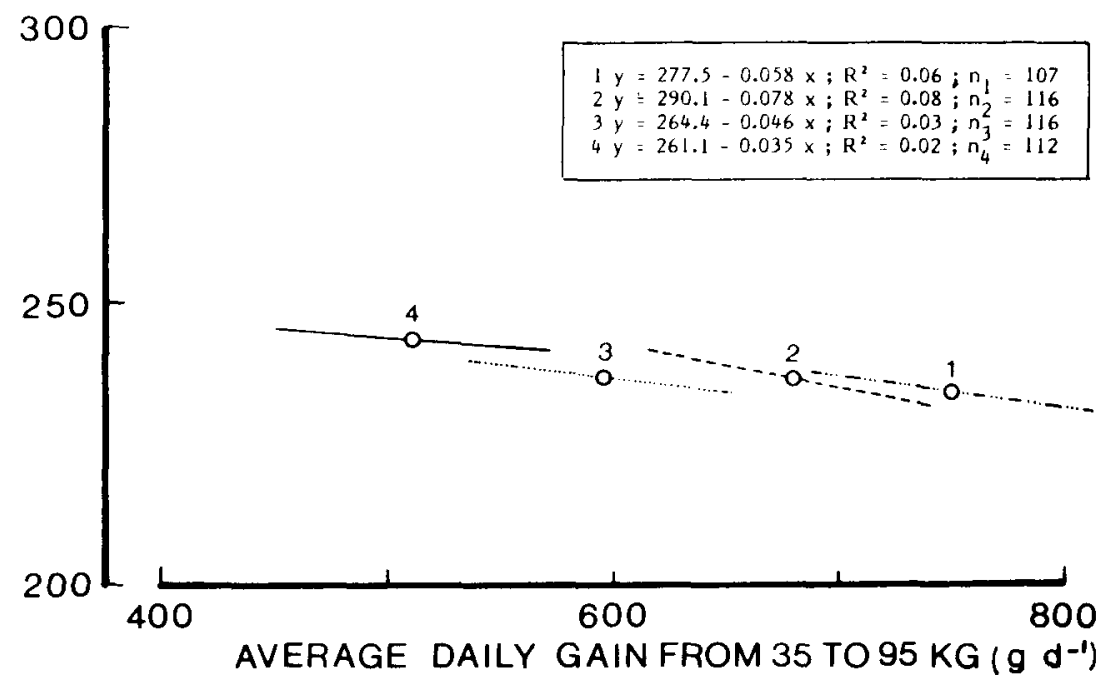

Fig. 7. Age at puberty and average daily gain of the gilts with a spontaneous oestrus for the four treatment groups.

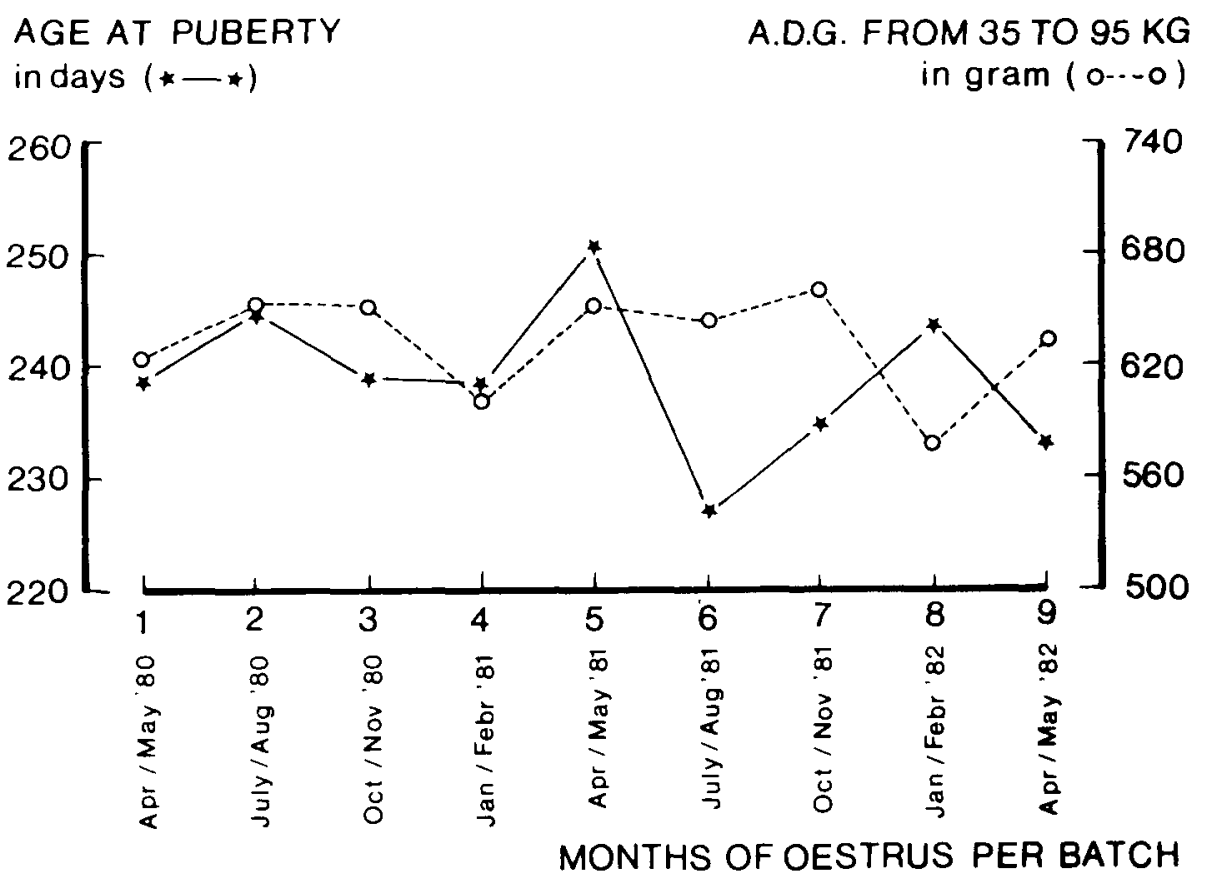

Fig. 8. Age at puberty $\left({ }^{*}=\right.$ days) and average daily gain $(\mathrm{o}=\mathrm{g}$ per day per gilt) for sows with a spontaneous oestrus in the subsequent batches. Both age and a.d.g. are scaled per unit of standard deviation. 


\section{Relationship between production traits and age at first oestrus}

According to the results given in Table 6, gilts with an induced oestrus showed a somewhat lower rate of gain from 35 to $95 \mathrm{~kg}$. They also tended to have less backfat at $99 \mathrm{~kg}$ and at 187 days than gilts with a spontaneous oestrus or no oestrus at all. The differences however were not significant $(P>0.05)$. Table 7 presents the overall and within treatment coefficients of correlation and regression between rate of gain, backfat thickness and age at puberty. Rate of gain from 35 to $95 \mathrm{~kg}$ was negatively correlated with age at puberty. Correlation coefficients between backfat thickness and age at puberty were also negative for the two highest levels of energy intake $(P<0.01)$ and close to zero for the two lowest energy level groups. It may be argued that the absence of the relation between age at puberty and backfat thickness at the low levels of energy intake may be associated with the larger variation in backfat thickness. Standard deviations of backfat thickness were even somewhat reduced at the low levels of energy intake compared to high levels of energy intake. Gilts fed on a high level (2.5 M or more) with more backfat at an age corrected weight of $99 \mathrm{~kg}$ reached oestrus at a younger age. One $\mathrm{mm}$ more backfat at that

Table 6. Rate of gain and backfat thickness at rearing for sows with a spontaneous and induced oestrus and for sows without an oestrus.

\begin{tabular}{llllll}
\hline & $\begin{array}{l}\text { Spontaneous } \\
\text { oestrus }\end{array}$ & $\begin{array}{l}\text { Induced } \\
\text { oestrus }\end{array}$ & $\begin{array}{l}\text { No oestrus } \\
\text { after induction }\end{array}$ & $\mathrm{CV}^{1}$ & Probability \\
$\begin{array}{c}\text { Average daily gain from } \\
\quad 35 \text { to } 95 \mathrm{~kg}\left(\mathrm{~g} \mathrm{~d}^{-1}\right)\end{array}$ & 636 & 619 & 624 & 18.9 & 0.08 \\
$\begin{array}{c}\text { Backfat thickness at } \\
99 \mathrm{~kg}(\mathrm{~mm})\end{array}$ & 11.5 & 11.2 & 11.6 & 17.1 & $0 . \overline{3} 0$ \\
187 days $(\mathrm{mm})$ & 11.1 & 10.5 & 11.1 & 22.6 & 0.07 \\
\hline
\end{tabular}

1 Coefficient of variation calculated as (residual standard deviation/mean) $\times 100$.

Table 7. Correlation and regression coefficients of production traits with age at first oestrus for gilts with a spontaneous oestrus (models 3 and 4 ).

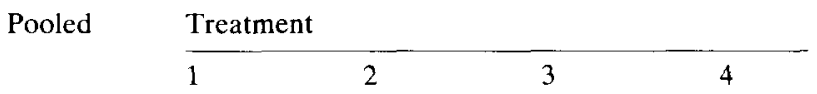

Coefficients of correlation of age at first oestrus with:

$\begin{array}{llllll}\text { average daily gain from } 35 \text { to } 95 \mathrm{~kg} & -0.26^{* * *} & -0.26^{* *} & -0.27^{* *} & -0.17^{*} & -0.14^{*} \\ \text { backfat thickness at } 99 \mathrm{~kg} & -0.22^{* * *} & -0.25^{* *} & -0.33^{* * *} & -0.06 & -0.01 \\ \text { backfat thickness at } 187 \text { days } & -0.26^{* * *} & -0.34^{* * *} & -0.28^{* * *} & -0.07 & -0.01\end{array}$

Regression coefficients of age at first oestrus with:

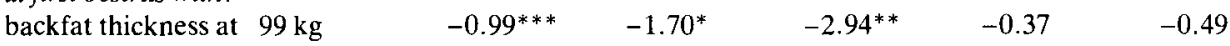
$\begin{array}{llllll}\text { backfat thickness at } 187 \text { days } & -1.01^{* * *} & -1.53^{*} & -2.58^{* *} & -0.16 & -0.92\end{array}$

${ }^{*} P<0.05$; $^{*} P<0.01 ;{ }^{* * *} P<0.001$. 
Table 8 . Fat gain per day until weight of $95 \mathrm{~kg}$ and until puberty and the fat content of the body for gilts with a spontaneous oestrus.

\begin{tabular}{|c|c|c|c|c|c|c|c|}
\hline \multirow[b]{3}{*}{ Fat gain from 35 to $95 \mathrm{~kg}(\mathrm{~g})$} & \multicolumn{4}{|c|}{ Treatment } & \multirow{3}{*}{$\begin{array}{l}\mathrm{CV}^{1} \\
14.4\end{array}$} & \multirow{2}{*}{\multicolumn{2}{|c|}{$\frac{\text { Probability }}{\text { treatment batch }}$}} \\
\hline & 1 & 2 & 3 & 4 & & & \\
\hline & 284 & 200 & 138 & 101 & & 0.00 & 0.22 \\
\hline Fat content of the body at $95 \mathrm{~kg}(\%)$ & 29.5 & 24.3 & 20.1 & 18.3 & 15.1 & 0.00 & 0.47 \\
\hline Fat gain from $95 \mathrm{~kg}$ to puberty $(\mathrm{g})$ & 420 & 319 & 238 & 165 & 16.0 & 0.00 & 0.00 \\
\hline Fat content of the body at puberty $(\%)$ & 38.4 & 30.8 & 24.9 & 20.9 & 6.9 & 0.00 & 0.00 \\
\hline
\end{tabular}

1 Coefficient of variation was calculated as (residual standard deviation/mean) $\times 100$.

weight resulted in 1.7 and 2.9 days earlier onset of first oestrus for gilts of Treatments 1 and 2 respectively. Gilts of Treatments 1 and 2 with $1 \mathrm{~mm}$ more backfat at 187 days of age corrected to a same weight, reached oestrus 1.5 and 2.6 days earlier, respectively. In gilts of Treatments 3 and 4 extra fat had no significant effect on age at first oestrus. When backfat thickness at $99 \mathrm{~kg}$ and at 187 days was not corrected for age and weight, respectively, at measuring, the regression coefficients were about 0.3 lower than those presented in Table 7 but the significance was the same. Fat gain from $35 \mathrm{~kg}$ to $95 \mathrm{~kg}$ and from $95 \mathrm{~kg}$ to oestrus differed significantly between treatments $(P<0.01$; see Table 8$)$. Calculated body fat content at $95 \mathrm{~kg}$ was $18.3 \%$ for gilts in the lowest energy level and increased to $29.5 \%$ for gilts in the highest level. At oestrus the calculated fat percentages for Treatments 1, 2, 3 and 4 were 38.4, 30.8, 24.9 and 20.9, respectively. Differences in fat gain and fat percentages between treatment groups were significant $(P<0.01)$.

\section{Discussion}

Reported experiments show a great variation in classifying feeding levels applied to breeding gilts. A high feeding level in one experiment, is referred to as low in another experiment (den Hartog \& van Kempen, 1980). In most studies the animals were given various energy and protein levels. In the present experiment, however, the gilts were only restricted in energy intake.

The protein intake in the present experiment was calculated on the basis of the lysine requirement. When the amino acid composition of the feed (Table 1) is compared with the requirements of the ARC (1981) it can be concluded that lysine was the first limiting amino acid in the rations used.

The greater culling rate at the high feeding levels agrees with results of experiments of the Regional Pig Research Centres in the Netherlands (Snoeyen, 1979; van Erp, 1980).

\section{Production traits}

Since most of the gilts reached the weight of $95 \mathrm{~kg}$ and since weights at various ages of gilts between treatments diverged nearly linearly (Fig. 2) rate of gain in the range of 35 to $95 \mathrm{~kg}$ was used to describe development of the gilts. The increased rate of gain, backfat thickness at $99 \mathrm{~kg}$ and at 187 days and fat gain per day at a higher level 
of energy intake agrees with data of Thorbek (1975), Gütte et al.(1979) and den Hartog \& Verstegen (1984). Increased protein gain per day at the higher levels of energy intake agrees with data of den Hartog \& Verstegen (1984). At the highest level of intake the fat gain as a percentage of the average daily gain in the range 35 to $95 \mathrm{~kg}$ was highest ( $38 \%$ ). For Treatments 2,3 and 4 these percentages were 29 , 23 and 20 , respectively. The fat gain, which was obtained with some assumptions (see den Hartog \& Verstegen, 1984), was only calculated in order to get an impression about the differences in fatness between the treatments. The calculated fat percentage of the gilts at the highest level of energy intake (Treatment 1) agrees very well with the data of Shields et al. (1983). Shields et al. determined body fat contents of ad libitum fed crossbred pigs by chemical analysis and found at $95 \mathrm{~kg}$ and $139 \mathrm{~kg}$ a fat percentage of 28.6 and 40.5 , respectively. Because the fat percentages are calculated on basis of pen data, backfat thickness was used for determining the relationship between fatness and reproductive performance. Despite the fact that less energy was required for maintenance, the increased fat gain in gilts of Treatment 1 caused an increased 'feed conversion' ratio. At the lower levels of energy intake the 'feed conversion' was nearly the same for the different treatments.

\section{Age and weight at puberty}

Studies on restricted energy resulting from restricted feed intake during rearing, as reported in the literature, resulted in:

- an earlier onset of oestrus (Hafez, 1960; MacPherson et al., 1977)

- no effect on oestrus (Pay \& Davies, 1973; Friend, 1977)

- a delayed onset of oestrus (Friend, 1976; Friend et al., 1981)

Addition of soya bean oil (energy) or soya been meal (crude protein) to diets for gilts had no influence on the onset of oestrus in the experiment of Friend (1977). In the present experiment, age at first oestrus for gilts at the lowest energy level was delayed by ten days compared to the highest energy level with levels 2 and 3 close to level 1 . The difference in number of gilts with a spontaneous oestrus, caused by different levels of energy intake was levelled out by the change of pen. The difference in age at first oestrus with adjusted data for gilts without a spontaneous oestrus between Treatment 1 and the other treatments was smaller than with only spontaneous oestrus. No clear difference in age at puberty exists between gilts of the three highest levels of energy intake. The difference in weight between animals at the lowest and highest energy level at puberty was $30 \mathrm{~kg}$. When weight at puberty is corrected to a similar age at that time the difference in weight at puberty is even greater. It can be concluded therefore that reaching puberty will be determined more by age than by weight within the range of energy supplied in the present studies.

Because the within-pen variance in age at first oestrus was lower than between pens for Treatments 1,2 and 4, it can be concluded that a gilt in oestrus can stimulate the onset of oestrus in other gilts in the pen.

NRLO (1979) concluded from data in literature that when the feed intake was less then $50 \%$ of ad libitum, onset of oestrus was delayed. In the present experiment the energy restriction was never below $60 \%$ of ad libitum. Despite this, a 
modest restriction showed a delayed onset of oestrus in the gilts at the lowest level of energy intake. At a higher restriction of energy intake effects on onset of oestrus will probably be still greater.

\section{Rate of gain}

According to Roth-Maier \& Kirchgessner (1976) breeding gilts need a rate of gain of $500 \mathrm{~g}$ per day from 20 to $120 \mathrm{~kg}$ to get normal reproductive results. Gilts at the lowest energy level had an average daily gain of $511 \mathrm{~g}$ from 35 to $95 \mathrm{~kg}$. The coefficient of correlation between rate of gain from $35 \mathrm{~kg}$ to $95 \mathrm{~kg}$ and age at puberty is negative at the high levels of energy intake but nearly absent for the two lower levels of energy intake. In most experiments a negative correlation between age at puberty and rate of gain is found also. Some workers, however, found no correlation at all or even a positive correlation (NRLO, 1979).

\section{Fatness}

In human females a negative relation is found between fatness and age at menarche. Girls with a high bodyfat content had a younger age at menarche (Frisch, 1975). It was thought that both a minimum and maximum fat content of the body act as threshold and limit, respectively, for puberty (den Hartog \& van Kempen, 1980). However, it seems that this is not true in all cases. In the present experiment, however, a high backfat thickness seems to be favourable for reaching oestrus at a young age.

Despite the great difference in rate of fat gain during rearing and the great difference in the fat content of the body at oestrus, age differences at puberty were relatively small for the treatment groups. The regression and correlation coefficients of backfat thickness with age at puberty within treatments are negative. For the two highest levels of energy intake these coefficients are significant $(P<0.01)$. At a lower feeding level age seems to be more important for reaching oestrus than fatness of the body. The relation between backfat thickness and age at puberty as reported in literature is nearly absent (Cunningham et al., 1974; Friend et al., 1981; Hutchens et al., 1981; van der Steen, 1983). The reproductive results in the experiment of van der Steen are comparable with those from the present experiment. Van der Steen used a restricted feeding scheme which resulted in the same rate of gain as gilts in treatment 3 of the present experiment. Relationship between fatness (backfat thickness) and age at puberty may be different for breeds maturing early or late. A genotype-diet interaction may exist for age at puberty (Cunningham et al., 1974). For example, fat Chinese pigs reach puberty at an average age of three months (Legault \& Caritez, 1982). Within feeding levels, backfat thickness was related to age at puberty at the two higher levels (Treatments 1 and 2) but no relationship was found at the low levels (Treatments 3 and 4; Table 7). Therefore it can be concluded that fatness is a threshold for reaching oestrus in animals of young age but is of reduced importance in older animals.

\section{Development of reproductive organs}

Friend (1976) found a positive relationship between the weight of a gilt and devel- 
opment (weight) of its reproductive organs. Etienne \& Legault (1974) and Herrmann \& Richter (1980), however, found no significant effects of feeding level on the development of uterus and ovaries in gilts. The development of uterus and ovaries was not measured in the present experiment, but it might be assumed that because of an older age at first oestrus this development was delayed at the lowest level.

\section{Oestrus induction}

The differences in rate of gain and backfat thickness between gilts with or without an oestrus were small. Data of Aherne \& Price (1979) showed that the average daily gain from 25 to $109 \mathrm{~kg}$ of crossbred gilts, which did not ovulate before the weight of $109 \mathrm{~kg}$ was significantly higher than for gilts with an ovulation ( 800 and $750 \mathrm{~g} \mathrm{~d}^{-1}$, respectively). They found no significant differences in slaughter and carcass traits. Rate of gain, however, was higher in their studies than found in the purebred gilts in the present experiment. The age at puberty and average daily gain were negatively correlated within the group of gilts with an ovulation before a weight of $109 \mathrm{~kg}$. This is in agreement with the results of the present experiment. Gilts with an induced oestrus had somewhat reduced values for rate of gain and backfat thickness (Table 6). A large number of the gilts which did not respond to a PG600 injection were gilts fed the highest energy level (Treatment 1). The contrasts in rate of gain and backfat thickness between the three groups mentioned in Table 6 were not significant within this treatment. Gilts which failed to respond to an oestrus induction could have another reason for that disorder than development. A too low basic level of the gonatotrope hormones available for the gilt is one of the possibilities ( $T$. Willemse, personal communication, 1983).

\section{References}

Aherne, F. X. \& M. A. Price, 1979. Relationship between age at puberty (first ovulation) and body composition at market weight in gilts. Proceedings 30th Annual Meeting EAAP, p. 5-11.

A.R.C., 1981. The nutrient requirements of pigs. Commonwealth Agricultural Bureaux, Slough, U.K., 307 pp.

Bongers, D., 1983. De bepaling van aminozuren. Dept. of Animal Physiology, Agricultural University, Wageningen. Unpublished.

Cunningham, P. J., C. H. Naber, D. R. Zimmerman \& E. R. Peo Jr., 1974. Influence of nutritional regime on age at puberty in gilts. Journal of Animal Science, 39: 63-67.

Du Mesnil du Buisson, F. \& J. P. Signoret, 1962. Influences de facteurs externes sur le déclenchement de la puberté chez la truie. Annales de Zootechnie 11: 53-59.

Erp, M. van, 1980. De invloed van het voederniveau van opfokzeugen op de latere gebruikseigenschappen. Internal report. Dept. of Animal Nutrition, Agricultural University, Wageningen, 22 pp.

Etienne, M. \& C. Legault, 1974. Influence de la race et du regime alimentaire sur la précocité sexuelle de la truie. Journées de Recherche Porcine en France, I.N.R.A., I.T.P., pp. 57-62.

Friend, D. W., 1976. Nutritional effects on age at puberty and plasma amino acid level in Yorkshire gilts and on chemical composition, nucleic acid, fatty acid and hydroxyproline contents of the uterus. Journal of Animal Science 43: 404-412.

Friend, D. W., 1977. Effect of dietary energy and protein on age and weight at puberty of gilts. Journal of Animal Science 44: 601-607.

Friend, D. W., G. A. Lodge \& J. I. Elliot, 1981. Effects of energy and dry matter intake on age, body weight and backfat at puberty and on embryo mortality in gilts. Journal of Animal Science 53: 118-124.

Netherlands Journal of Agricultural Science 32 (1984) 
Frisch, R. E., 1975. The physiological basis of reproductive efficiency. In: D. Luster, D. N. Rhodes, V. R. Fowler \& M. F. Fuller (Eds.), Meat animals, growth and productivity, pp. 327-354. Plenum Press, New York/London.

Gütte, J. O., E. Heunisch \& T. Heine, 1979. Untersuchungen zum Einfluss unterschiedlicher Energieversorgung auf Wachstum, Futterverwertung und Zusammensetzung des Körpers von Schweinen 3. Der mittlere tägliche Stoffansatz im Tierkörper von 25 bis $99 \mathrm{~kg}$. Lebendgewicht. Zeitschrift für Tierphysiologie, Tierernährung und Futtermittelkunde 41: 177-184.

Hafez, E. S. E., 1960. Nutrition in relation to reproduction in sows. Journal of Agricultural Science 54: 170-178.

Hartog, L. A. den, 1980. De relatie voeding-vruchtbaarheid bij (opfok)zeugen. Dept. of Animal Nutrition, Agricultural University, Wageningen, $55 \mathrm{pp}$.

Hartog, L. A. den \& G. J. M. van Kempen, 1980. Relation between nutrition and fertility in pigs. Netherlands Journal of Agricultural Science 28: 211-227.

Hartog, L. A. den \& M. W. A. Verstegen, 1984. The effect of energy intake of gilts on the supply of metabolizable energy and protein deposition. Netherlands Journal of Agricultural Science 32: 87-99.

Hemmer, H., 1984. Genetische en milieu-invloeden op uniformiteit van tomen bij geboorte van NL varkens. Internal report. Dept. of Animal Nutrition, Agricultural University, Wageningen, $45 \mathrm{pp}$.

Herrmann, U. \& K. Richter, 1980. Untersuchungen zur Beeinflussung von Merkmalen der Geslechtsreife durch ein reguliertes Energieangebot in der Aufzucht weiblicher Jungschweine. Tagungsbericht Akademie der Landwirtschaftswissenschaften der DDR 176: 79-85.

Hutchens, L. K., R. L. Hintz \& R. K. Johnson, 1981. Genetic and phenotypic relationships between puberal and growth characteristics of gilts. Journal of Animal Science 53: 946-951.

Legault, C., 1970. Etudé statistique et génétique des performances d'élevages des truies de race Large White II. Effet direct du verrat heritabilité, répétabilité, correlations. Annales de Génétique et de Sélection Animale 2: 209-227.

Legault, C. \& J. C. Caritez, 1982. Premier bilan de l'experimentation sur le porc Chinois en France. I. Performances de reproduction en race pure et en croisement. Journées de Recherche Porcine en France 14: 127-136.

MacPherson, R. M., F. D. Hovell \& A. S. Jones, 1977. Performance of sows first mated at puberty or second or third oestrus, and carcass assessment of once bred gilts. Animal Production 24: 333-342.

NRLO (Nationale Raad voor Landbouwkundig Onderzoek) 1979. De vruchtbaarheid van het vrouwelijk varken. Rapport B-133, IVO 'Schoonoord', Zeist, 157 pp.

Pay, M. G. \& T. E. Davies, 1973. Growth, food consumption and litter production of female pigs mated at puberty and at low body weights. Animal Production 17: 85-91.

Rerat, A \& P. H. Duée, 1975. Ernährung und Reproduktion der Sau. Übersicht Tierernährung 3: 101141.

Roth-Maier, D. A. \& M. Kirchgessner, 1976. Aufzuchtintensität und Fruchtbarkeitsleistung der Sau. Bayerisches Landwirtschiftliches Jahrbuch 53: 71-80.

Shearer, I. J. \& J. L. Adams, 1973. Nutritional and physiological developments in reproduction of pigs. Proceedings New Zealand Society of Animal Production 33: 62.

Shields, Jr., R. G., D. C. Mahan \& P. L. Graham, 1983. Changes in swine body composition from birth to $145 \mathrm{~kg}$. Journal of Animal Science 57: 43-54.

Snoeyen, P., 1979. De invloed van het voerniveau van opfokzeugen op de latere gebruikseigenschappen van fokzeugen. Internal report. Dept. of Animal Nutrition, Agricultural University, Wageningen, 14 pp.

Steen, H. A. M. van der, 1983. Maternal and genetic influences on production and reproduction traits in pigs. Doctoral theseis, Agricultural University, Wageningen, $112 \mathrm{pp}$.

Thorbek, G., 1975. Studies on energy metabolism in growing pigs II. Beretning Statens, Husdyrbrugsforsøg, København 424, 193 pp.

Vermeeren, C. T. M. E., 1981. Voedervoorkeur bij varkens. Internal report, Dept. of Animal Nutrition, Agricultural University, Wageningen, $14 \mathrm{pp}$.

Wilde, R. de, 1977. Studie van een methode ter bepaling van eiwit- en energieretenties bij mestvarkens gebaseerd op karkasanalyse. Thesis, Faculty of Veterinary Medicine, State University Ghent, 211 pp. 